\title{
The Role of Lexical Resources in CJK Natural Language Processing
}

\author{
Jack Halpern（春遍雀來） \\ The CJK Dictionary Institute (CJKI) (日中韓辭典研究所) \\ 34-14, 2-chome, Tohoku, Niiza-shi, Saitama 352-0001, Japan \\ jack@cjk.org
}

\begin{abstract}
The role of lexical resources is often understated in NLP research. The complexity of Chinese, Japanese and Korean (CJK) poses special challenges to developers of NLP tools, especially in the area of word segmentation (WS), information retrieval (IR), named entity extraction (NER), and machine translation (MT). These difficulties are exacerbated by the lack of comprehensive lexical resources, especially for proper nouns, and the lack of a standardized orthography, especially in Japanese. This paper summarizes some of the major linguistic issues in the development NLP applications that are dependent on lexical resources, and discusses the central role such resources should play in enhancing the accuracy of NLP tools.
\end{abstract}

\section{Introduction}

Developers of CJK NLP tools face various challenges, some of the major ones being:

1.Identifying and processing the large number of orthographic variants in Japanese, and alternate character forms in CJK languages.

2. The lack of easily available comprehensive lexical resources, especially lexical databases, comparable to the major European languages.

3. The accurate conversion between Simplified and Traditional Chinese (Halpern and Kerman 1999).

4. The morphological complexity of Japanese and Korean.

5. Accurate word segmentation (Emerson 2000 and $\mathrm{Yu}$ et al. 2000) and disambiguating ambiguous segmentations strings (ASS) (Zhou and $\mathrm{Yu}$ 1994).

6. The difficulty of lexeme-based retrieval and CJK CLIR (Goto et al. 2001).
7.Chinese and Japanese proper nouns, which are very numerous, are difficult to detect without a lexicon.

8. Automatic recognition of terms and their variants (Jacquemin 2001).

The various attempts to tackle these tasks by statistical and algorithmic methods (Kwok 1997) have had only limited success. An important motivation for such methodology has been the poor availability and high cost of acquiring and maintaining large-scale lexical databases.

This paper discusses how a lexicon-driven approach exploiting large-scale lexical databases can offer reliable solutions to some of the principal issues, based on over a decade of experience in building such databases for NLP applications.

\section{Named Entity Extraction}

Named Entity Recognition (NER) is useful in NLP applications such as question answering, machine translation and information extraction. A major difficulty in NER, and a strong motivation for using tools based on probabilistic methods, is that the compilation and maintenance of large entity databases is time consuming and expensive. The number of personal names and their variants (e.g. over a hundred ways to spell $\mathrm{Mo}$ hammed) is probably in the billions. The number of place names is also large, though they are relatively stable compared with the names of organizations and products, which change frequently.

A small number of organizations, including The CJK Dictionary Institute (CJKI), maintain databases of millions of proper nouns, but even such comprehensive databases cannot be kept fully up-to-date as countless new names are created daily. Various techniques have been used to automatically detect entities, one being the use of keywords or syntactic structures that co-occur with proper nouns, which we refer to as named entity contextual clues (NECC). 
Table 1. Named Entity Contextual Clues

\begin{tabular}{|l|l|l|}
\hline Headword & \multicolumn{1}{|c|}{ Reading } & \multicolumn{1}{|c|}{ Example } \\
\hline センター & せんたー & 国民生活センター \\
\hline ホテル & ほてる & ホテルシオノ \\
\hline 駅 & えき & 朝霞駅 \\
\hline 協会 & きょうかい & 日本ユニセフ協会 \\
\hline
\end{tabular}

Table 1 shows NECCs for Japanese proper nouns, which when used in conjunction with entity lexicons like the one shown in Table 2 below achieve high precision in entity recognition. Of course for NER there is no need for such lexicons to be multilingual, though it is obviously essential for MT.

Table 2. Multilingual Database of Place Names

\begin{tabular}{|l|l|l|l|l|l|}
\hline \multicolumn{1}{|c|}{ English } & \multicolumn{1}{|c|}{ Japanese } & $\begin{array}{c}\text { Simplified } \\
\text { Chinese }\end{array}$ & LO & $\begin{array}{l}\text { Traditional } \\
\text { Chinese }\end{array}$ & \multicolumn{1}{|c|}{ Korean } \\
\hline Azerbaijan & アゼルバイジャン & 阿塞拜疆 & L & 亞塞拜然 & 아제르바이잔 \\
\hline Caracas & カラカス & 加拉加斯 & L & 卡拉卡斯 & 카라카스 \\
\hline Cairo & カイロ & 开罗 & O & 開羅 & 카이로 \\
\hline Chad & チャド & 乍得 & L & 查德 & 차드 \\
\hline New Zealand & ニュージーランド & 新西兰 & L & 紐西蘭 & 뉴질랜드 \\
\hline Seoul & ソウル & 首尔 & O & 首爾 & 서울 \\
\hline Seoul & ソウル & 汉城 & O & 漢城 & 서울 \\
\hline Yemen & イエメン & 也门 & L & 葉門 & 예멘 \\
\hline
\end{tabular}

Note how the lexemic pairs ("L" in the LO column) in Table 2 above are not merely simplified and traditional orthographic ("O") versions of each other, but independent lexemes equivalent to American truck and British lorry.

NER, especially of personal names and place names, is an area in which lexicon-driven methods have a clear advantage over probabilistic methods and in which the role of lexical resources should be a central one.

\section{Linguistic Issues in Chinese}

\subsection{Processing Multiword Units}

A major issue for Chinese segmentors is how to treat compound words and multiword lexical units (MWU), which are often decomposed into their components rather than treated as single units. For example, 录像带 lùxiàngdài 'video cassette' and 机器翻译 jīqifānyì 'machine translation' are not tagged as segments in Chinese Gigaword, the largest tagged Chinese corpus in existence, processed by the CKIP morphological analyzer (Ma 2003). Possible reasons for this include:

1. The lexicons used by Chinese segmentors are small-scale or incomplete. Our testing of vari- ous Chinese segmentors has shown that coverage of MWUs is often limited.

2. Chinese linguists disagree on the concept of wordhood in Chinese. Various theories such as the Lexical Integrity Hypothesis (Huang 1984) have been proposed. Packard's outstanding book (Packard 98) on the subject clears up much of the confusion.

3. The "correct" segmentation can depend on the application, and there are various segmentation standards. For example, a search engine user looking for 录像带 is not normally interested in 录像 'to videotape' and 带 'belt' per se, unless they are part of 录像带.

This last point is important enough to merit elaboration. A user searching for 中国人 zhōngguórén 'Chinese (person)' is not interested in 中国 'China', and vice-versa. A search for 中 国 should not retrieve 中国人 as an instance of 中国. Exactly the same logic should apply to 机 器翻译, so that a search for that keyword should only retrieve documents containing that string in its entirety. Yet performing a Google search on 机器翻译 in normal mode gave some 2.3 million hits, hundreds of thousands of which had zero occurrences of 机器翻译 but numerous 
occurrences of unrelated words like 机器人 'robot', which the user is not interested in.

This is equivalent to saying that headwaiter should not be considered an instance of waiter, which is indeed how Google behaves. More to the point, English space-delimited lexemes like high school are not instances of the adjective high. As shown in Halpern (2000b), "the degree of solidity often has nothing to do with the status of a string as a lexeme. School bus is just as legitimate a lexeme as is headwaiter or wordprocessor. The presence or absence of spaces or hyphens, that is, the orthography, does not determine the lexemic status of a string."

In a similar manner, it is perfectly legitimate to consider Chinese MWUs like those shown below as indivisible units for most applications, especially information retrieval and machine translation.

\section{丝绸之路 sīchóuzhīlù silk road \\ 机器翻译 jīqifānyi machine translation \\ 爱国主义 àiguózhǔyi patriotism \\ 录像带 lùxiàngdài video cassette \\ 新西兰 Xìnxīlán New Zealand \\ 临阵磨枪 línzhènmóqiāng \\ start to prepare at the last moment}

One could argue that 机器翻译 is compositional and therefore should be considered "two words." Whether we count it as one or two "words" is not really relevant - what matters is that it is one lexeme (smallest distinctive units associating meaning with form). On the other extreme, it is clear that idiomatic expressions like 临阵磨枪, literally "sharpen one's spear before going to battle," meaning 'start to prepare at the last moment,' are indivisible units.

Predicting compositionality is not trivial and often impossible. For many purposes, the only practical solution is to consider all lexemes as indivisible. Nonetheless, currently even the most advanced segmentors fail to identify such lexemes and missegment them into their constituents, no doubt because they are not registered in the lexicon. This is an area in which expanded lexical resources can significantly improve segmentation accuracy.

In conclusion, lexical items like 机器翻译 'machine translation' represent stand-alone, welldefined concepts and should be treated as single units. The fact that in English machineless is spelled solid and machine translation is not is an historical accident of orthography unrelated to the fundamental fact that both are full-fledged lexemes each of which represents an indivisible, independent concept. The same logic applies to 机器翻译, which is a full-fledged lexeme that should not be decomposed.

\subsection{Multilevel Segmentation}

Chinese MWUs can consist of nested components that can be segmented in different ways for different levels to satisfy the requirements of different segmentation standards. The example below shows how 北京日本人学校 Běijing Riběnrén Xuéxiào 'Beijing School for Japanese (nationals)' can be segmented on five different levels.

1. 北京日本人学校 multiword lexemic

2. 北京 + 日本人+学校 lexemic

3. 北京 + 日本 + 人 + 学校 sublexemic

4. 北京 $+[$ 日本 + 人 $][$ 学 + 校 $]$ morphemic

5. [北+京] [日 + 本 + 人] [学+校] submorphemic

For some applications, such as MT and NER, the multiword lexemic level is most appropriate (the level most commonly used in CJKI's dictionaries). For others, such as embedded speech technology where dictionary size matters, the lexemic level is best. A more advanced and expensive solution is to store presegmented MWUs in the lexicon, or even to store nesting delimiters as shown above, making it possible to select the desired segmentation level.

The problem of incorrect segmentation is especially obvious in the case of neologisms. Of course no lexical database can expect to keep up with the latest neologisms, and even the first edition of Chinese Gigaword does not yet have 博客 bókè 'blog'. Here are some examples of MWU neologisms, some of which are not (at least bilingually), compositional but fully qualify as lexemes.

$$
\begin{aligned}
& \text { 电脑迷 diànnăomí cyberphile } \\
& \text { 电子商务 diànzǐshāngwù e-commerce } \\
& \text { 追车族 zhuīchēzú auto fan }
\end{aligned}
$$

\subsection{Chinese-to-Chinese Conversion (C2C)}

Numerous Chinese characters underwent drastic simplifications in the postwar period. Chinese written in these simplified forms is called Simplified Chinese (SC). Taiwan, Hong Kong, and most overseas Chinese continue to use the old, complex forms, referred to as Traditional Chinese (TC). Contrary to popular perception, the 
process of accurately converting SC to/from TC is full of complexities and pitfalls. The linguistic issues are discussed in Halpern and Kerman (1999), while technical issues are described in Lunde (1999). The conversion can be implemented on three levels in increasing order of sophistication:

1. Code Conversion. The easiest, but most unreliable, way to perform $\mathrm{C} 2 \mathrm{C}$ is to transcode by using a one-to-one mapping table. Because of the numerous one-to-many ambiguities, as shown below, the rate of conversion failure is unacceptably high.

Table 3. Code Conversion

\begin{tabular}{|l|l|l|l|l|l|}
\hline SC & TC1 & TC2 & TC3 & TC4 & Remarks \\
\hline 门 & 們 & & & & one-to-one \\
\hline 汤 & 湯 & & & & one-to-one \\
\hline 发 & 發 & 髮 & & & one-to-many \\
\hline 暗 & 暗 & 闇 & & & one-to-many \\
\hline 干 & 幹 & 乾 & 干 & 翰 & one-to-many \\
\hline
\end{tabular}

2. Orthographic Conversion. The next level of sophistication is to convert orthographic units, rather than codepoints. That is, meaningful linguistic units, equivalent to lexemes, with the important difference that the TC is the traditional version of the $\mathrm{SC}$ on a character form level. While code conversion is ambiguous, orthographic conversion gives much better results because the orthographic mapping tables enable conversion on the lexeme level, as shown below.

Table 4. Orthographic Conversion

\begin{tabular}{|l|l|l|l|l|}
\hline English & \multicolumn{1}{|c|}{ SC } & TC1 & TC2 & Incorrect \\
\hline Telephone & 电话 & 電話 & & \\
\hline Dry & 干燥 & 乾燥 & & 干燥 幹燥 畭燥 \\
\hline & 阴干 & 陰乾 & 陰干 & \\
\hline
\end{tabular}

As can be seen, the ambiguities inherent in code conversion are resolved by using orthographic mapping tables, which avoids false conversions such as shown in the Incorrect column. Because of segmentation ambiguities, such conversion must be done with a segmentor that can break the text stream into meaningful units (Emerson 2000).

An extra complication, among various others, is that some lexemes have one-to-many orthographic mappings, all of which are correct. For example, SC 阴干 correctly maps to both TC 陰 乾 'dry in the shade' and TC 陰干 'the five even numbers'. Well designed orthographic mapping tables must take such anomalies into account.

3. Lexemic Conversion. The most sophisticated form of $\mathrm{C} 2 \mathrm{C}$ conversion is called lexemic conversion, which maps $\mathrm{SC}$ and $\mathrm{TC}$ lexemes that are semantically, not orthographically, equivalent. For example, SC 信息 xinxī 'information' is converted into the semantically equivalent TC 資訊 zixxùn. This is similar to the difference between British pavement and American sidewalk. Tsou (2000) has demonstrated that there are numerous lexemic differences between SC and TC, especially in technical terms and proper nouns, e.g. there are more than 10 variants for Osama bin Laden.

Table 5. Lexemic Conversion

\begin{tabular}{|l|l|l|l|l|}
\hline English & \multicolumn{1}{|c|}{ SC } & Taiwan TC & HK TC & $\begin{array}{l}\text { Incorrect } \\
\text { TC }\end{array}$ \\
\hline Software & 软件 & 軟體 & 軟件 & 軟件 \\
\hline Taxi & 出租汽车 & 計程車 & 的士 & 出租汽車 \\
\hline $\begin{array}{l}\text { Osama } \\
\text { Bin } \\
\text { Laden }\end{array}$ & $\begin{array}{l}\text { 奥萨马 } \\
\text { 本拉登 }\end{array}$ & $\begin{array}{l}\text { 奧薩瑪賓 } \\
\text { 拉登 }\end{array}$ & $\begin{array}{l}\text { 奥薩瑪 } \\
\text { 賓拉丹 }\end{array}$ & $\begin{array}{l}\text { 奧薩馬本 } \\
\text { 拉登 }\end{array}$ \\
\hline Oahu & 瓦胡岛 & 歐胡島 & & 瓦胡島 \\
\hline
\end{tabular}

\subsection{Traditional Chinese Variants}

Traditional Chinese has numerous variant character forms, leading to much confusion. Disambiguating these variants can be done by using mapping tables such as the one shown below. If such a table is carefully constructed by limiting it to cases of $100 \%$ semantic interchangeability for polysemes, it is easy to normalize a TC text by trivially replacing variants by their standardized forms. For this to work, all relevant components, such as MT dictionaries, search engine indexes and the related documents should be normalized. An extra complication is that Taiwanese and Hong Kong variants are sometimes different (Tsou 2000).

Table 6. TC Variants

\begin{tabular}{|l|l|l|l|}
\hline Var. 1 & Var. 2 & \multicolumn{1}{|c|}{ English } & \multicolumn{1}{c|}{ Comment } \\
\hline 裏 & 裡 & Inside & $100 \%$ interchangeable \\
\hline 著 & 着 & Particle & variant 2 not in Big5 \\
\hline 沉 & 沈 & sink; surname & partially interchangeable \\
\hline
\end{tabular}




\section{Orthographic Variation in Japanese}

\subsection{Highly Irregular Orthography}

The Japanese orthography is highly irregular, significantly more so than any other major language, including Chinese. A major factor is the complex interaction of the four scripts used to write Japanese, e.g. kanji, hiragana, katakana, and the Latin alphabet, resulting in countless words that can be written in a variety of often unpredictable ways, and the lack of a standardized orthography. For example, toriatsukai 'handling' can be written in six ways: 取り扱い, 取 扱い，取扱，とり扱い，取りあつかい，とり あつかい。

An example of how difficult Japanese IR can be is the proverbial 'A hen that lays golden eggs.' The "standard" orthography would be 金の卵を 産む鶏 Kin no tamago o umu niwatori. In reality, tamago 'egg' has four variants (卵, 玉子, た まご, タマゴ), niwatori 'chicken' three (䳕, に わとり, ニワトリ) and $u m u$ 'to lay' two (産む, 生む), which expands to 24 permutations like 金 の卵を生むニワトリ，金の玉子を産む鶏 etc. As can be easily verified by searching the web, these variants occur frequently.

Linguistic tools that perform segmentation, MT, entity extraction and the like must identify and/or normalize such variants to perform dictionary lookup. Below is a brief discussion of what kind of variation occurs and how such normalization can be achieved.

\subsection{Okurigana Variants}

One of the most common types of orthographic variation in Japanese occurs in kana endings, called okurigana, that are attached to a kanji stem. For example, okonau 'perform' can be written 行う or 行なう, whereas toriatsukai can be written in the six ways shown above. Okurigana variants are numerous and unpredictable. Identifying them must play a major role in Japanese orthographic normalization. Although it is possible to create a dictionary of okurigana variants algorithmically, the resulting lexicon would be huge and may create numerous false positives not semantically interchangeable. The most effective solution is to use a lexicon of okurigana variants, such as the one shown below:
Table 7. Okurigana Variants

\begin{tabular}{|l|l|l|}
\hline \multicolumn{1}{|c|}{ HEADWORD } & \multicolumn{1}{c|}{ READING } & NORMALIZED \\
\hline 書き著す & かきあらわす & 書き著す \\
\hline 書き著わす & かきあらわす & 書き著す \\
\hline 書著す & かきあらわす & 書き著す \\
\hline 書著わす & かきあらわす & 書き著す \\
\hline
\end{tabular}

Since Japanese is highly agglutinative and verbs can have numerous inflected forms, a lexicon such as the above must be used in conjunction with a morphological analyzer that can do accurate stemming, i.e. be capable of recognizing that 書き著しませんでした is the polite form of the canonical form 書き著す.

\subsection{Cross-Script Orthographic Variation}

Variation across the four scripts in Japanese is common and unpredictable, so that the same word can be written in any of several scripts, or even as a hybrid of multiple scripts, as shown below:

Table 8. Cross-Script Variation

\begin{tabular}{|l|l|l|l|l|l|}
\hline Kanji & Hiragana & katakana & Latin & Hybrid & Gloss \\
\hline 人参 & にんじん & ニンジン & & & carrot \\
\hline & & オープン & OPEN & & open \\
\hline 硫黄 & & イオウ & & & sulfur \\
\hline & & ワイシャツ & & Y シャツ & shirt \\
\hline 皮膚 & & ヒフ & & 皮フ & skin \\
\hline
\end{tabular}

Cross-script variation can have major consequences for recall, as can be seen from the table below.

Table 9: Hit Distribution for 人参 'carrot' ninjin

\begin{tabular}{|l|l|l|l|}
\hline ID & Keyword & $\begin{array}{c}\text { Normal- } \\
\text { ized }\end{array}$ & $\begin{array}{c}\text { Google } \\
\text { Hits }\end{array}$ \\
\hline A & 人参 & 人参 & 67,500 \\
\hline B & にんじん & 人参 & 66,200 \\
\hline C & ニンジン & 人参 & 58,000 \\
\hline
\end{tabular}

Using the ID above to represent the number of Google hits, this gives a total of $\mathrm{A}+\mathrm{B}+\mathrm{C}+\alpha_{123}$ $=191,700 . \alpha$ is a coincidental occurrence factor, such as in '100 人参加, in which '人参' is unrelated to the 'carrot' sense. The formulae for calculating the above are as follows. 
Unnormalized recall:

$$
\frac{C}{A+B+C+\alpha_{123}}=\frac{58,000}{191,700}(\approx 30 \%)
$$

Normalized recall:

$$
\frac{A+B+C}{A+B+C+\alpha}=\frac{191,700}{191,700}(\approx 100 \%)
$$

Unnormalized precision:

$$
\frac{C}{C+\alpha}=\frac{58,000}{58,000}(\approx 100 \%)
$$

Normalized precision:

$$
\frac{C}{A+B+C+\alpha_{123}}=\frac{191,700}{191,700}(\approx 100 \%)
$$

人参 'carrot' illustrates how serious a problem cross-orthographic variants can be. If orthographic normalization is not implemented to ensure that all variants are indexed on a standardized form like 人参, recall is only $30 \%$; if it is, there is a dramatic improvement and recall goes up to nearly $100 \%$, without any loss in precision, which hovers at $100 \%$.

\subsection{Kana Variants}

A sharp increase in the use of katakana in recent years is a major annoyance to NLP applications because katakana orthography is often irregular; it is quite common for the same word to be written in multiple, unpredictable ways. Although hiragana orthography is generally regular, a small number of irregularities persist. Some of the major types of kana variation are shown in the table below.

Table 10. Kana Variants

\begin{tabular}{|l|l|l|l|}
\hline \multicolumn{1}{|c|}{ Type } & English & \multicolumn{1}{c|}{ Standard } & \multicolumn{1}{c|}{ Variants } \\
\hline Macron & computer & コンピュータ & コンピューター \\
\hline Long vowels & maid & メード & メイド \\
\hline Multiple kana & team & チーム & ティーム \\
\hline Traditional & big & おおきい & おうきい \\
\hline づ vs. ず & continue & つづく & つずく \\
\hline
\end{tabular}

The above is only a brief introduction to the most important types of kana variation. Though attempts at algorithmic solutions have been made by some NLP research laboratories (Brill 2001), the most practical solution is to use a katakana normalization table, such as the one shown below, as is being done by Yahoo! Japan and other major portals.
Table 11. Kana Variants

\begin{tabular}{|c|c|c|}
\hline HEADWORD & NORMALIZED & English \\
\hline アーキテクチャ & アーキテクチャー & Architecture \\
\hline アーキテクチャー & アーキテクチャー & Architecture \\
\hline アーキテクチュア & アーキテクチャー & Architecture \\
\hline
\end{tabular}

\subsection{Miscellaneous Variants}

There are various other types of orthographic variants in Japanese, described in Halpern (2000a). To mention some, kanji even in contemporary Japanese sometimes have variants, such as 才 for 歳 and 巾 for 幅, and traditional forms such as 發 for 発. In addition, many kun homophones and their variable orthography are often close or even identical in meaning, i.e., noboru means 'go up' when written 上る but 'climb' when written 登る, so that great care must be taken in the normalization process so as to assure semantic interchangeability for all senses of polysemes; that is, to ensure that such forms are excluded from the normalization table.

\subsection{Lexicon-driven Normalization}

Leaving statistical methods aside, lexicondriven normalization of Japanese orthographic variants can be achieved by using an orthographic mapping table such as the one shown below, using various techniques such as:

1. Convert variants to a standardized form for indexing.

2. Normalize queries for dictionary lookup.

3. Normalize all source documents.

4. Identify forms as members of a variant group.

Table 12. Orthographic Normalization Table

\begin{tabular}{|l|l|l|}
\hline HEADWORD & READING & NORMALIZED \\
\hline 空き缶 & あきかん & 空き缶 \\
\hline 空缶 & あきかん & 空き缶 \\
\hline 明き罐 & あきかん & 空き缶 \\
\hline あき缶 & あきかん & 空き缶 \\
\hline あき罐 & あきかん & 空き缶 \\
\hline 空きかん & あきかん & 空き缶 \\
\hline 空きカン & あきかん & 空き缶 \\
\hline 空き罐 & あきかん & 空き缶 \\
\hline 空罐 & あきかん & 空き缶 \\
\hline 空き鑵 & あきかん & 空き缶 \\
\hline 空鑵 & あきかん & 空き缶 \\
\hline
\end{tabular}


Other possibilities for normalization include advanced applications such as domain-specific synonym expansion, requiring Japanese thesauri based on domain ontologies, as is done by a select number of companies like Wand and Convera who build sophisticated Japanese IR systems.

\section{Orthographic Variation in Korean}

Modern Korean has is a significant amount of orthographic variation, though far less than in Japanese. Combined with the morphological complexity of the language, this poses various challenges to developers of NLP tools. The issues are similar to Japanese in principle but differ in detail.

Briefly, Korean has variant hangul spellings in the writing of loanwords, such as 케이크 keikeu and 케익 keik for 'cake', and in the writing of non-Korean personal names, such as 클린턴 keulrinteon and 클린톤 keulrinton for 'Clinton'. In addition, similar to Japanese but on a smaller scale, Korean is written in a mixture of hangul, Chinese characters and the Latin alphabet. For example, 'shirt' can be written 와이셔츠 wai-syeacheu or Y 셔츠 wai-syeacheu, whereas 'one o'clock' hanzi can written as 한시, 1 시 or 一時. Another issue is the differences between South and North Korea spellings, such as N.K. 오사까 osakka vs. S.K. 오사카 osaka for 'Osaka', and the old (pre-1988) orthography versus the new, i.e. modern 일군 'worker' (ilgun) used to be written 일꾼 (ilkkun).

Lexical databases, such as normalization tables similar to the ones shown above for Japanese, are the only practical solution to identifying such variants, as they are in principle unpredictable.

\section{The Role of Lexical Databases}

Because of the irregular orthography of CJK languages, procedures such as orthographic normalization cannot be based on statistical and probabilistic methods (e.g. bigramming) alone, not to speak of pure algorithmic methods. Many attempts have been made along these lines, as for example Brill (2001) and Goto et al. (2001), with some claiming performance equivalent to lexicon-driven methods, while Kwok (1997) reports good results with only a small lexicon and simple segmentor.
Emerson (2000) and others have reported that a robust morphological analyzer capable of processing lexemes, rather than bigrams or ngrams, must be supported by a large-scale computational lexicon. This experience is shared by many of the world's major portals and MT developers, who make extensive use of lexical databases.

Unlike in the past, disk storage is no longer a major issue. Many researchers and developers, such as Prof. Franz Guenthner of the University of Munich, have come to realize that "language is in the data," and "the data is in the dictionary," even to the point of compiling full-form dictionaries with millions of entries rather than rely on statistical methods, such as Meaningful Machines who use a full form dictionary containing millions of entries in developing a human quality Spanish-to-English MT system.

CJKI, which specializes in CJK and Arabic computational lexicography, is engaged in an ongoing research and development effort to compile CJK and Arabic lexical databases (currently about seven million entries), with special emphasis on proper nouns, orthographic normalization, and $\mathrm{C} 2 \mathrm{C}$. These resources are being subjected to heavy industrial use under realworld conditions, and the feedback thereof is being used to further expand these databases and to enhance the effectiveness of the NLP tools based on them.

\section{Conclusions}

Performing such tasks as orthographic normalization and named entity extraction accurately is beyond the ability of statistical methods alone, not to speak of $\mathrm{C} 2 \mathrm{C}$ conversion and morphological analysis. However, the small-scale lexical resources currently used by many NLP tools are inadequate to these tasks. Because of the irregular orthography of the CJK writing systems, lexical databases fine-tuned to the needs of NLP applications are required. The building of large-scale lexicons based on corpora consisting of even billions of words has come of age. Since lexicon-driven techniques have proven their effectiveness, there is no need to overly rely on probabilistic methods. Comprehensive, up-todate lexical resources are the key to achieving major enhancements in NLP technology. 


\section{References}

Brill, E. and Kacmarick, G. and Brocket, C. (2001) Automatically Harvesting Katakana-English Term Pairs from Search Engine Query Logs. Microsoft Research, Proc. of the Sixth Natural Language Processing Pacific Rim Symposium, Tokyo, Japan.

Packard, L. Jerome (1998) "New Approaches to Chinese Word Formation", Mouton Degruyter, Berlin and New York.

Emerson, T. (2000) Segmenting Chinese in Unicode. Proc. of the 16th International Unicode Conference, Amsterdam

Goto, I., Uratani, N. and Ehara T. (2001) CrossLanguage Information Retrieval of Proper Nouns using Context Information. NHK Science and Technical Research Laboratories. Proc. of the Sixth Natural Language Processing Pacific Rim Symposium, Tokyo, Japan

Huang, James C. (1984) Phrase Structure, Lexical Integrity, and Chinese Compounds, Journal of the Chinese Teachers Language Association, 19.2: 5378

Jacquemin, C. (2001) Spotting and Discovering Terms through Natural Language Processing. The MIT Press, Cambridge, MA

Halpern, J. and Kerman J. (1999) The Pitfalls and Complexities of Chinese to Chinese Conversion. Proc. of the Fourteenth International Unicode Conference in Cambridge, MA.

Halpern, J. (2000a) The Challenges of Intelligent Japanese Searching. Working paper (www.cjk.org/cjk/joa/joapaper.htm), The CJK Dictionary Institute, Saitama, Japan.

Halpern, J. (2000b) Is English Segmentation Trivial?. Working paper, (www.cjk.org/cjk/reference/engmorph.htm) The CJK Dictionary Institute, Saitama, Japan.

Kwok, K.L. (1997) Lexicon Effects on Chinese Information Retrieval. Proc. of 2nd Conf. on Empirical Methods in NLP. ACL. pp.141-8.

Lunde, Ken (1999) CJKV Information Processing. O’Reilly \& Associates, Sebastopol, CA.

$\mathrm{Yu}$, Shiwen, Zhu, Xue-feng and Wang, Hui (2000) New Progress of the Grammatical Knowledgebase of Contemporary Chinese. Journal of Chinese Information Processing, Institute of Computational Linguistics, Peking University, Vol.15 No.1.

Ma, Wei-yun and Chen, Keh-Jiann (2003) Introduction to CKIP Chinese Word Segmentation System for the First International Chinese Word Segmentation Bakeoff, Proceedings of the Second
SIGHAN Workshop on Chinese Language Processingpp. 168-171 Sapporo, Japan

Yu, Shiwen, Zhu, Xue-feng and Wang, Hui (2000) New Progress of the Grammatical Knowledgebase of Contemporary Chinese. Journal of Chinese Information Processing, Institute of Computational Linguistics, Peking University, Vol.15 No.1.

Tsou, B.K., Tsoi, W.F., Lai, T.B.Y. Hu, J., and Chan S.W.K. (2000) LIVAC, a Chinese synchronous corpus, and some applications. In "2000 International Conference on Chinese Language ComputingICCLC2000", Chicago.

Zhou, Qiang. and Yu, Shiwen (1994) Blending Segmentation with Tagging in Chinese Language Corpus Processing, 15th International Conference on Computational Linguistics (COLING 1994) 